\title{
Capital Market and Economic Development: A Comparative Study of Three Sub-Saharan African Emerging Economies
}

\author{
Francis Uju Adoms ${ }^{1,2}$, Henry Yua2,3, Celestine S. Okaro², Kelechukwu Stanley Ogbonna² \\ ${ }^{1}$ Addyfx Limited, Lagos, Nigeria \\ ${ }^{2}$ Banking and Finance Department, Nnamdi Azikiwe University, Awka, Nigeria \\ ${ }^{3}$ Banking and Finance Department, Nigerian Army College of Environmental Studies and Technology, Makurdi, Nigeria \\ Email: adomskf@gmail.com, henryyua@yahoo.com, cs.okaro@unizik.edu.ng,ks.ogbonna@unizik.edu.ng
}

How to cite this paper: Adoms, F. U., Yua, H., Okaro, C. S., \& Ogbonna, K. S. (2020). Capital Market and Economic Development: A Comparative Study of Three Sub-Saharan African Emerging Economies. American Journal of Industrial and Business Management, 10, 963-987.

https://doi.org/10.4236/ajibm.2020.105065

Received: April 19, 2020

Accepted: May 19, 2020

Published: May 22, 2020

Copyright $\odot 2020$ by author(s) and Scientific Research Publishing Inc. This work is licensed under the Creative Commons Attribution International License (CC BY 4.0).

http://creativecommons.org/licenses/by/4.0/

\begin{abstract}
The study is undertaken with the objective of examining the relationship between capital market and economic development in emerging African economies. The study adopted an ex-post facto research design for Nigeria, South Africa and Kenya and the variables used were Human Development Index (HDI) as the dependent variable, Stock Market Capitalization (SMC); Value of Stock Traded (VST); Stock Market Turnover Ratio (TR) as independent variable. Moreover, the period under study was from 1990 to 2018 and the data collected within the period were analysed using descriptive statistics, ARDL regression, granger causality and Ordinary Least Square (OLS) for the comparative single country regression analysis. The study empirically proves that capital market has a significant relationship with economic development in the selected emerging Africa economies in Nigeria and South Africa except for Kenya which conforms with the Finance Led Growth Hypothesis Theory. We recommend that Governments of Sub-Saharan African economies should formulate and implement policies that will ensure relative stability in the market-based stock market of the economy to foster capital formation, increase investment and ensure stability in the financial system.
\end{abstract}

\section{Keywords}

Capital Market, Economic Development, Stock Market \& Market Capitalization

\section{Introduction}

Economic development is primary objective of every developing economy in the 
world. The African Sub-Saharan economy is primed to pursue precisely economic development. However, different mechanism has been employed to achieve this primary goal of the region. One of such mechanism is developing an efficient capital market among others to boost the redistribution of funds both within and across countries into the economy. Thus, capital market and economic development in the sub-Saharan African (SSA) emerging economies have been the rejuvenated focus of a large body of enquiry. The long-term market in Africa has witnessed considerable development since the early 1990s, due to the advent of stock market, commodities and trading institutions. Due to the rapid expansion of these institutions, there has also been a significant upward growth in market capitalization and the number of listed companies. As at June 2016, $50 \%$ of the 54 African countries have securities exchanges-which lead the way to the formation of African Securities Exchange Association (ASEA) which was earlier incorporated in Kenya in 1993. Hence, the World Bank believes that economies in the continent could be on the brink of an economic acceleration (World Bank, 2011). For instance, in 2013 SSA, real economy grew by $12.29 \%$ and by 2017 grew to $254.64 \%$ but reduced by $1.4 \%$ in the fourth quarter of 2019 respectively, while African countries were expected to grow as one of the fastest growing economies in the world (World Bank, 2020; Statsza, 2020).

However, from 2011 to 2015, Africa has witnessed 441 Equity Capital Market (ECM) transactions raising a total of $\$ 41.3$ billion and a record of 28 listings, at a five-year peak. Between 2011 and 2015, there were 105 Initial Public Offering (IPO's) by African companies on both African and international exchanges and non-African companies in African exchanges raising a total of $\$ 6.1$ billion. Despite the volatility in global ECM, companies continue to be attracted to African markets (Moime, 2016).

Focusing on the three selected SSA countries (Nigeria, South Africa and Kenya), Nigeria record shows that market capitalization was $\$ 2.373$ billion as at 2002 and grew drastically to $\$ 84.874$ billion in 2007 at over $3577 \%$ growth but fell drastically the next year to $\$ 48.062$ billion in 2008 by $-43.36 \%$ (World Bank, 2019). As at 2014 , the market capitalization was $\$ 62.766$ billion and fell continuously to $\$ 49.973$ billion in 2015 and further to $\$ 29,792$ billion in 2016 at $-20.38 \%$ and $-40.38 \%$ respectively; by the end period of study in 2017 , the market capitalization was $\$ 37.217$ billion. In South Africa, the market capitalization maintains a high figure all through from \$147.471 billion in 2001 to $\$ 828.185$ billion in 2007. The market capitalization ended at $\$ 951.320$ billion in 2016 . By 2017, the market capitalization was $\$ 1230$ billion (World Bank, 2019). However, Kenya's market capitalization was $\$ 1.431$ billion in 2002 and grew to $\$ 4.182$ billion in 2003 at $192.21 \%$ but had the highest market capitalization in 2010 at $\$ 14.460$ billion. The market capitalization fell in 2011 to $\$ 10.202$ billion by $-29.45 \%$, but in 2016 the market capitalization was $\$ 57.783$ billion (World Bank, 2018). Furthermore, in Nigeria, HDI went on a steady increase from $44 \%$ in 2003 to $53 \%$ in 2017, but it wasn't reflecting on the economy because Inflation went from an all-time low during the period of study $5.40 \%$ in 2007 to $16.5 \%$ in 
2017. Also, capital market performance dived further from a $20.45 \%$ in 2007 to $8.20 \%$ turnover ratio in 2018. This was not the same for South Africa, for there was a boom in capital market performance in 2007 but an immediate sharp decline in $2008 \$ 482$ billion and a recovery at $\$ 925$ billion in 2010. During these periods, HDI went on an increase from $62 \%$ in 2007 to $63 \%$ in 2008 , and the increase continued to $70 \%$ in 2017 . During the increase in HDI, it didn't reflect in inflation in that same period, inflation stood at $6.2 \%$ in 2007 but later declined in 2010 at $4.10 \%$. The Kenyan economy grew consistently from 1990 to 2017, HDI was seen growing steadily from $47 \%$ in 2007 to $59 \%$ in 2017 . But the case was different for that of capital market performance, turnover ratio declined from $11.99 \%$ in 2006 to $1.81 \%$ in 2009 and later increased to $10.02 \%$ in 2015 (World Bank, 2019). This shows that South Africa has been more efficient in the African stock exchange compared to the other two stock exchanges under study.

Looking at the Human Development Index in Africa, no African economies are among the first fifty (50) economies in terms of development. While Norway is the highest in ranking in the world, South Africa is ranked $112^{\text {th }}$ followed by Kenya ranked $141^{\text {st }}$ and Nigeria ranked $156^{\text {th }}$ in the world with HDI of 70\%, 59\% and $53 \%$ respectively as at 2017 . This showed that regardless of the economic growth in GDP of the various countries that showed South Africa ranked before Nigeria then Kenya, there are varying positions between economic growth and economic development of economies. Thus, regardless of their ranking, the question that how has capital market affected the economic development of the emerging sub-Saharan African economies in Nigeria, Kenya and South Africa.

Finally, another motive for development of a capital market is that the emerging market economies are expected to play a bigger role in driving development. Following this, efforts have been done in other to create an enabling environment for the successful and efficient operation of the stock exchange through a sound regulatory body, capacity building, and safe and robust securities markets in those countries. Thus, the engineered soundness of a robust capital market is anticipated to improve the economic development of sub-Sahara African emerging economies. Hence, the purpose of this study is to investigate the relationship between capital market and economic development of Sub-Saharan African emerging economies.

\section{Review of Related Literature}

Capital market is the market for the mobilization and utilization of long-term funds for development (Anyanwu, 1993; Jhingan, 2005). Capital market supplies industry with fixed and working capital and finance medium-term and long-term borrowings of the central, state and local governments (Rose \& Marquis, 2009; Mishkin, 2007; Nwaolisa, Kasie, \& Egbunike, 2013). Thus, the capital market is a highly specialized, organized and indeed essential agent of economic development because of its ability to facilitate and mobilize saving and investment via the financial market.

In the Sub-Saharan African economies for instance, stock exchange like the Nigerian stock exchange, the Johannesburg stock exchange and the Kenyan 
stock exchange have played key roles in resource mobilization to economic development African. These different stock exchanges have a connecting tool that allow trade across co-countries and none co-countries to boost availability of funds or transactions in the market thereby enhancing the movement and flow of funds from the saving surplus economy to the saving deficit economy of the world to boost economic development of Africa.

\section{Theoretical Review}

However, the activities of the capital market are influenced by diverse theories that militate for and mitigate flows of funds. Thus, the different theories like the Neoclassical theories, Harrod and Domar Growth model and the Finance Led Growth hypothesis all made their postulation on the possible advantages of capital market on economic position. However, the Finance Led Growth hypothesis is discussed. The positive view of finance-led growth focuses on the role played by finance in mobilizing domestic savings and investments through a more open and liberalized financial system and promoting productivity through creation of efficient capital markets. Schumpeter (1912) is believed to have laid the foundation for the finance led growth hypothesis. He contends that a well-functioning financial system will spur technological innovations through efficiency of resource allocation from unproductive sector to productive sector. Goldsmith (1969) builds on the finance-led growth hypothesis. He contends that evolution of domestic financial markets may enhance and lead to high level of capital accumulation. Furthermore, Levine (1996), argue that stock market liquidity; the ability to trade equity easily is important for growth/development.

This proposition is one that we wish to prove or rebut in this study, to know whether changes in capital market actually leads to proportionate changes in economic growth or otherwise. Following the background of this theory, it is adopted as the theoretical framework for this study.

\section{Empirical review}

Capital markets act as a connection tool between monetary and real sector and therefore smoothen the process of growth in the real sector and economic development. The nexus between capital market and economic growth has been empirically investigated by researchers in Nigeria, South Africa, Kenya and other emerging and developed countries of the world. However, this study is centered on capital market and economic development thus the following empirical review; Osakwe, Ogbonna, and Obi-Nwosu (2020) examined stock market capitalization on economic growth in Nigeria and South Africa for the period 2000-2018. The study discovered that the relationship between market capitalization ratio to GDP and economic growth is positive for South Africa but insignificant for Nigeria. Thus, the economic growth is positively correlated with the size of both countries' capital markets, though the size of South Africa capital market has better contribution to economic growth compared to Nigeria. Nwamuo (2018) studied impact of capital market on the economic growth in Nigeria from 1981 to 2016 and discovered that market capitalization and number of deals have a positive impact on the economic growth in Nigeria while total listed 
equity and volume of transaction have a negative impact on the economic growth in Nigeria in the short run. Osakwe and Ananwude (2017), looked at the short-run and long-run relationship between stock market development and economic growth in two emerging economies in Africa namely Nigeria and South Africa discovered that in both short and long run, there was a positive but insignificant relationship between stock market development and economic growth in Nigeria and South Africa. Further results revealed that economic growth significantly affects market capitalization of South Africa, while having insignificant effect on market capitalization in Nigeria. This South Africa result was confirmed by the study of Cuthbert (2017), who examined the long-run causal relationship between stock market development and economic growth in South Africa. He concluded that stock market development Granger-causes economic growth and vice versa.

Okoro (2016) looking at a comparative analysis on stock market performance and augmentation of frontier economies: Nigeria and Mauritius during 2006-2010. The findings revealed that stock market performance for Mauritius was superior to Nigeria and same for GDP.

Okoye, Modebe, Taiwo, and Okorie (2016) investigated the relationship between capital market development and economic growth over the period 1981-2014 in Nigeria. Using VECM, MC-Ratio and T-ratio have significant negative effect and positive effect of VT-ratio were revealed as well as negatively insignificant effect of inflation rate on aggregate national output (GDP). Their long-run estimate showed that all the regressors have significantly negative impact on GDP. Their result further showed that MC-ratio, VT-ratio and T-ratio granger cause changes in the aggregate national output, thus revealing a unidirectional causality from GDP to inflation. Taiwo, Adedayo, and Evawere (2016) evaluating the contribution of capital market to the growth of Nigeria's economy also established the same findings as Okoye, Modebe, Taiwo, and Okorie (2016).

Bilal, Chen, and Komal (2016) studied the effect of stock market development on economic growth using panel data techniques by fixed effects and random effects for 20 Lower-Middle Income countries from 1990 to 2012 and discovered that there is positive and significant effect of stock market development on economic growth.

Onwe (2015) investigated the impact of capital market on economic growth of Nigeria between the periods of 1990-2013. Their study revealed a significant impact of capital market components in Market capitalization (MCAP), all share index (ASI), Total value for Transactions (VLT) and Turnover ratio (TO) on economic growth in Nigeria. This contradicted later studies in Nwamuo (2018), Osakwe and Ananwude (2017) and Adeoye (2015) who examined the impact of the Nigerian Capital Market on the Nigerian economy between the period 1992 to 2011. The findings revealed that Capital Market has an insignificant impact on the Economy.

The study of Ruwaydah and Ushad (2015) on macroeconomic determinant of stock market development in the Southern African Development Communities 
(SADC) from 1980 to 2011, discovered that a strong link between stock market development and economic growth using pooled panel data set. Another panel data study in the relationship between stock market development and economic growth in 17 emerging market and 10 developed market economies from 2000 to 2011 by Hailemariam and Guotai (2014) discovered that stock market development has significant relationship with economic growth both directly and indirectly. Thus, affirming that economic growth is determined by the development in the stock market.

The study of Yadirichukwu and Chigbu (2014) and Adefeso, Egbetunde, and Alley (2013) revealed the presence of significant relationship between stock market development and economic growth in Nigeria. Both Yadirichukwu and Chigbu (2014) and Adefeso, Egbetunde, and Alley (2013) used multivariate co-integration and error correction model for their study and covered different periods of 1985 to 2012 and 1980 to 2010 respectively.

Kareem, Sanni, Raheem, and Bakare (2013) and Ogege and Ozike (2012) confirm the existence of significant relationship between Nigerian capital market components and economic growth (RGDP).

Looking at stock market performance components of market capitalization, All-Shares Index, value of transactions in the market, the total number of listed companies in the Nigerian Stock Market and economic growth in GDP between 1984 and 2011; Ihendinihu and Onwuchekwa (2012) discovered that market capitalization and value of transaction significantly related to economic growth while the other variables had little relationship both in the long run and short run

Aduda, Masila, and Onsongo (2012) covering 2005 and 2009 revealed that stock market liquidity, institutional quality, income per capita, domestic savings and bank development are important determinants of stock market development in Kenya. This finding was supported by Tobias and Danson (2011) study of stock market performance and economic growth between 2001 and 2010 in Kenya.

Akinlo and Egbetunde (2010) looking at multiple African economies in Central African Republic, Congo, Gabon, Nigeria, Zambia, Kenya, Chad, South Africa, Sierra Leone and Swaziland discovered that financial development has long-run relationship and granger cause economic growth in the 10 Sub-Saharan African economies. However, a single country study in Cameroun between 2006 and 2010 by Ake and Ognaligui (2010) showed that stock market (Douala stock exchange) does not affect economic growth in Cameroun.

Odhiambo (2009) and Ndako (2009) both study stock market development and economic growth in South Africa differently; while Odhiambo (2009) discovered that stock market development Granger-cause economic, Ndako (2009) says the direct opposite: economic growth Granger-cause stock market development; all in same country, with similar time series data.

The inconsistencies in results of empirical review and the usage of economic 
growth components for economic development necessitated the need to inquire into how capital market has affected economic development components in HDI for the three countries under consideration.

\section{Methodology}

The study used ex-post facto research design and data were derived from World Bank Data base. The study covers the period of 28 years from 1991 to 2018. The study adopts Osakwe and Ananwude (2017). Their model is stated thus:

$$
\text { GDPGRt }=b_{0}+b_{1} \mathrm{MKTCRt}+b_{2} \mathrm{SVTRt}+\mu_{t}
$$

(Osakwe \& Ananwude, 2017) where, GDPGRt-Gross Domestic Product, MKTCRt-Market Capitalization Ratio to Gross Domestic Product and SVTRt-Stock Value Traded Ratio to Gross Domestic Product.

The OLS regression models take the form

$$
\begin{gathered}
Y=f(X) \\
Y=b_{0}+b_{1} X_{1}+U \\
\mathrm{HDI}=f(\mathrm{SMC}) \\
\mathrm{HDI}=b_{0}+b_{1} \mathrm{SMC}+U \\
\mathrm{HDI}=f(\mathrm{VST}) \\
\mathrm{HDI}=b_{0}+b_{1} \mathrm{VST}+U \\
\mathrm{HDI}=f(\mathrm{TR}) \\
\mathrm{HDI}=b_{0}+b_{1} \mathrm{TR}+U \\
\mathrm{HDI}=f(\mathrm{INF}) \\
\mathrm{HDI}=b_{0}+b_{1} \mathrm{INF}+U
\end{gathered}
$$

Functional form Mathematical form

Restatement in a multiple regression form is stated thus:

$$
\begin{gathered}
\mathrm{HDI}=f(\mathrm{SMC}, \mathrm{VST}, \mathrm{TR}, \mathrm{INF}) \\
\mathrm{HDI}=b_{0}+b_{1} \mathrm{SMC}+b_{2} \mathrm{VST}+b_{3} \mathrm{TR}+b_{4} \mathrm{INF}+U
\end{gathered}
$$

where $Y$ is the dependent variable; the $X_{s}$ are the independent variables; and the $b_{s}$ the parameters, HDI-Human Development Index, SMC-Stock Market Capitalization, VST-Total Value of Stocks Traded, TR-Stock Market Turnover Ratio, INF-Inflation.

The log-linear function takes the form.

$$
\log _{s} Y=\log _{e} b_{0}+b_{1} \log _{e} x_{1} \times b_{2} \log _{e} X_{2}+\cdots+b_{n} \log _{e} X_{n}+U .
$$

\section{Presentation and Analysis of Results}

This section is divided into three subsections. The unit root test is presented first, followed by cointegration tests. This leads to the presentation of the Panel Co-integration and Granger analysis for the countries. 
The stationarity outcome in Table 1 reports that the tests for stationarity properties of the series following the Augmented Dickey Fuller (ADF) statistics were found to be stationery at level and order one (1). At the First difference as reported, the $\mathrm{ADF}$ Statistics for the respective variables were all negative than the critical values at $5 \%$ significance level. The reported $P$-values were all less than 0.05 chosen level of significance for which cause, the Null Hypothesis of the presence of unit root in all the variables is convincingly rejected.

The unit root outcome in Table 2 showed that all the variables following the Augmented Dickey Fuller (ADF) statistics were stationery at level and order one (1). At both level and first difference as reported, the ADF Statistics for the respective variables were all negative than the critical values at $5 \%$ significance level. The reported $P$-values were less than 0.05 chosen level of significance for which cause, the Null Hypothesis of the presence of unit root in all the variables is convincingly rejected.

The result of Table 3 reports the tests stationarity properties of all the variables following the Augmented Dickey Fuller (ADF) statistics which were stationery at order one (1). At the first difference as reported, the ADF Statistics for

Table 1. Unit root tests for Nigeria data.

\begin{tabular}{ccccc}
\hline Variables & ADF Test Statistics & Critical Values @ 5\% & $\boldsymbol{P}$-value & Order of Integration \\
\hline D(HDI) & -4.107560 & -3.580623 & 0.0163 & $\mathrm{I}(0)$ \\
D(SMC) & -5.798528 & -2.976263 & 0.0001 & $\mathrm{I}(1)$ \\
D(TR) & -5.484560 & -2.976263 & 0.0001 & $\mathrm{I}(1)$ \\
D(VST) & -4.805514 & -2.976263 & 0.0007 & $\mathrm{I}(1)$ \\
\hline
\end{tabular}

Source: Computation by researcher using E-view 10.0.

Table 2. Unit root tests for Kenya data.

\begin{tabular}{ccccc}
\hline Variables & ADF Test Statistics & Critical Values @ 5\% & $\boldsymbol{P}$-value & Order of Integration \\
\hline D(HDI) & -3.523961 & -2.976263 & 0.0150 & $\mathrm{I}(\mathrm{I})$ \\
D(SMC) & -3.719519 & -2.971853 & 0.0093 & $\mathrm{I}(0)$ \\
D(TR) & -4.010721 & -2.971853 & 0.0046 & $\mathrm{I}(0)$ \\
D(VST) & -5.520205 & -2.976263 & 0.0001 & $\mathrm{I}(1)$ \\
\hline
\end{tabular}

Source: Computation by researcher using E-view 10.0.

Table 3. Unit root tests for South Africa data.

\begin{tabular}{ccccc}
\hline Variables & ADF Test Statistics & Critical Values @ 5\% & $\boldsymbol{P}$-value & Order of Integration \\
\hline D(HDI) & -4.842114 & -2.976263 & 0.0006 & $\mathrm{I}(\mathrm{I})$ \\
D(SMC) & -6.282567 & -2.976263 & 0.0000 & $\mathrm{I}(1)$ \\
D(TR) & -6.437292 & -2.976263 & 0.0000 & $\mathrm{I}(1)$ \\
D(VST) & -4.835787 & -2.976263 & 0.0006 & $\mathrm{I}(1)$ \\
\hline
\end{tabular}

Source: Computation by researcher using E-view 10.0. 
the respective variables were all negative than the critical values at $5 \%$ significance level. The reported $P$-values were all less than 0.05 chosen level of significance for which cause, the Null Hypothesis of the presence of unit root in all the variables is convincingly rejected.

For the purposes of Co-integration analysis and tests, ARDL Bound and Long-term Co-integration analysis will be conducted and it is also interesting to state that the variables are all integrated of the mixed order for two countries Nigeria and Kenya except South Africa.

\section{Tests for Co-integration}

Co-integration is used in Finance to model long-run equilibrium relationship (Brooks, 2014). Co-integration methods have been used in several established researches to test for long-run equilibrium relationship (Levine \& Zervos, 1998 and Soumaré \& Tchana, 2015). These form the basis for our adoption of co-integration method to test for the existence of long-run equilibrium relationship before we can proceed with our regression analysis.

\section{Individual Country Co-integration Test}

The results of the ARDL bounds testing approach as shown in Table 4 indicates that the F-statistic with a coefficient of 1.420853 is less than the lower bound value 3.1 and upper bound value of 3.63 at $5 \%$ level of confidence. Thus, no level of long-run relationship was established in the study. This is evident in the case 2 of Table 2. The insignificant t-bound distributional relationship at 0.653827 significance level which is less than the confidence/significance of the

Table 4. ARDL co-integration test result for Nigeria @ 5\% level (F-Statistics).

\begin{tabular}{|c|c|c|c|c|}
\hline \multicolumn{2}{|c|}{ F-Bounds Test } & \multicolumn{3}{|c|}{ Null Hypothesis: No levels relationship } \\
\hline \multirow[t]{2}{*}{ Test Statistic } & Value & Signif. & $\mathrm{I}(0)$ & $\mathrm{I}(1)$ \\
\hline & & \multicolumn{3}{|c|}{$\begin{array}{c}\text { Asymptotic: } \\
\mathrm{n}=1000\end{array}$} \\
\hline F-statistic & 1.420853 & $10 \%$ & 2.01 & 3.1 \\
\hline \multirow[t]{3}{*}{$\mathrm{K}$} & 3 & $5 \%$ & 2.45 & 3.63 \\
\hline & & $2.5 \%$ & 2.87 & 4.16 \\
\hline & & $1 \%$ & 3.42 & 4.84 \\
\hline Actual Sample Size & 27 & \multicolumn{3}{|c|}{$\begin{array}{l}\text { Finite Sample: } \\
\qquad \mathrm{n}=35\end{array}$} \\
\hline \multicolumn{2}{|c|}{ t-Bounds Test } & \multicolumn{3}{|c|}{ Null Hypothesis: No levels relationship } \\
\hline Test Statistic & Value & Signif. & $\mathrm{I}(0)$ & $\mathrm{I}(1)$ \\
\hline \multirow[t]{4}{*}{ t-statistic } & 0.653827 & $10 \%$ & -1.62 & -3 \\
\hline & & $5 \%$ & -1.95 & -3.33 \\
\hline & & $2.5 \%$ & -2.24 & -3.64 \\
\hline & & $1 \%$ & -2.58 & -3.97 \\
\hline
\end{tabular}

Source: Computation by researcher using E-view 10.0. 
study. Therefore, the empirical findings provide that there is no long-run relationship between capital market and economic development of Nigeria.

The results of the ARDL bounds testing approach as shown in Table 5 indicates that the F-statistic with a coefficient of 3.358341 is more than the lower bound value 3.1 and less than the upper bound value of 3.63 at $5 \%$ level of confidence. Thus, strong level of long-run relationship was established in the study. However, the insignificant t-bound distributional relationship at -0.801293 significance level which is less than the confidence/significance of the study. Therefore, the empirical findings provide that there is a long-run relationship between capital market and economic development of Kenya.

The results of the ARDL bounds testing approach as shown in Table 6 indicates that the F-statistic with a coefficient of 3.916985 is more than the lower bound value 3.1 and the upper bound value of 3.63 at $5 \%$ level of confidence. Thus, strong level of long-run relationship was established in the study. However, the insignificant $t$-bound distributional relationship at -0.202154 significance level which is less than the confidence/significance of the study. Therefore, the empirical findings provide that there is a long-run relationship between capital market and economic development of South Africa.

From Table 7, the result established that the capital market variables in Nigeria showed that there is no presence of a long-run relationship in the study. While in Kenya and South Africa, the capital market variables prove that there was long-run relationship with economic development with F-statistics of 3.358341 and 3.916985 which is above the lower bound at $5 \%$ level of significance respectively.

Table 5. ARDL co-integration test result for Kenya @ 5\% level (F-Statistics).

\begin{tabular}{|c|c|c|c|c|}
\hline \multicolumn{2}{|c|}{ F-Bounds Test } & \multicolumn{3}{|c|}{ Null Hypothesis: No levels relationship } \\
\hline \multirow[t]{2}{*}{ Test Statistic } & \multirow[t]{2}{*}{ Value } & Signif. & $\mathrm{I}(0)$ & $\mathrm{I}(1)$ \\
\hline & & \multicolumn{3}{|c|}{$\begin{array}{l}\text { Asymptotic: } \\
\mathrm{n}=1000\end{array}$} \\
\hline F-statistic & 3.358341 & $10 \%$ & 2.01 & 3.1 \\
\hline \multirow[t]{3}{*}{$\mathrm{K}$} & 3 & $5 \%$ & 2.45 & 3.63 \\
\hline & & $2.5 \%$ & 2.87 & 4.16 \\
\hline & & $1 \%$ & 3.42 & 4.84 \\
\hline Actual Sample Size & 27 & \multicolumn{3}{|c|}{$\begin{array}{l}\text { Finite Sample: } \\
\qquad \mathrm{n}=35\end{array}$} \\
\hline \multicolumn{2}{|c|}{ t-Bounds Test } & \multicolumn{3}{|c|}{ Null Hypothesis: No levels relationship } \\
\hline Test Statistic & Value & Signif. & $\mathrm{I}(0)$ & $\mathrm{I}(1)$ \\
\hline \multirow[t]{4}{*}{ t-statistic } & -0.801293 & $10 \%$ & -1.62 & -3 \\
\hline & & $5 \%$ & -1.95 & -3.33 \\
\hline & & $2.5 \%$ & -2.24 & -3.64 \\
\hline & & $1 \%$ & -2.58 & -3.97 \\
\hline
\end{tabular}

Source: Computation by researcher using E-view 10.0. 
Table 6. ARDL Co-integration test result for South Africa @ 5\% level (F-Statistics).

\begin{tabular}{|c|c|c|c|c|}
\hline \multicolumn{2}{|c|}{ F-Bounds Test } & \multicolumn{3}{|c|}{ Null Hypothesis: No levels relationship } \\
\hline \multirow[t]{2}{*}{ Test Statistic } & \multirow[t]{2}{*}{ Value } & Signif. & $\mathrm{I}(0)$ & $\mathrm{I}(1)$ \\
\hline & & \multicolumn{3}{|c|}{$\begin{array}{l}\text { Asymptotic: } \\
\mathrm{n}=1000\end{array}$} \\
\hline F-statistic & 3.916985 & $10 \%$ & 2.01 & 3.1 \\
\hline \multirow[t]{3}{*}{$\mathrm{K}$} & 3 & $5 \%$ & 2.45 & 3.63 \\
\hline & & $2.5 \%$ & 2.87 & 4.16 \\
\hline & & $1 \%$ & 3.42 & 4.84 \\
\hline Actual Sample Size & 27 & \multicolumn{3}{|c|}{$\begin{array}{l}\text { Finite Sample: } \\
\quad \mathrm{n}=35\end{array}$} \\
\hline \multicolumn{2}{|c|}{ t-Bounds Test } & \multicolumn{3}{|c|}{ Null Hypothesis: No levels relationship } \\
\hline Test Statistic & Value & Signif. & $\mathrm{I}(0)$ & $\mathrm{I}(1)$ \\
\hline \multirow[t]{4}{*}{ t-statistic } & -0.202154 & $10 \%$ & -1.62 & -3 \\
\hline & & $5 \%$ & -1.95 & -3.33 \\
\hline & & $2.5 \%$ & -2.24 & -3.64 \\
\hline & & $1 \%$ & -2.58 & -3.97 \\
\hline
\end{tabular}

Source: Computation by researcher using E-view 10.0.

Table 7. Comparison of co-integration results.

\begin{tabular}{cccccc}
\hline Signif. & Lower Bound & Upper Bound & $\begin{array}{c}\text { Nigeria } \\
\text { F-statistic }\end{array}$ & $\begin{array}{c}\text { Kenya } \\
\text { F-statistic }\end{array}$ & $\begin{array}{c}\text { South Africa } \\
\text { F-statistic }\end{array}$ \\
\hline $10 \%$ & 2.01 & 3.1 & & & \\
$5 \%$ & 2.45 & 3.63 & 1.420853 & 3.358341 & 3.916985 \\
$2.5 \%$ & 2.87 & 4.16 & & & \\
$1 \%$ & 3.42 & 4.84 & Accept Ho & Reject Ho & Reject Ho \\
\hline
\end{tabular}

Source: Computation by researcher using E-view 10.0.

Thus, the capital market components are significantly related to the economic development in the long run in Kenya and South Africa, while the capital market is not significantly related economic development in the long run with Nigeria. Hence, capital market components thus will affect economic development in the long run in Kenya and South Africa while the capital market variables for Nigeria no significant impact in the long run.

\section{Test of Hypothesis}

This Sub-section tests the hypotheses stated in chapter one and modelled in chapter three. In testing for these hypotheses, we proceeded to test the data for each country in the study area, to ascertain the individual country results.

\section{Test of Hypothesis One (1)}

$\mathrm{Ho}_{1}$ : Stock Market Capitalization had no significant relationship with Human Development Index (HDI) of selected Sub-Saharan African emerging economies. 
$\mathrm{HA}_{1}$ : Stock Market Capitalization had significant relationship with Human Development Index (HDI) of selected Sub-Saharan African emerging economies.

In Table 8 , the $\mathrm{R}^{2}$ and Adjusted $\mathrm{R}^{2}$ both showed $90.23 \%$ and $84.38 \%$ respectively. This shows that the chosen regression model best fits the data. Hence, the goodness of fit regression model is $90.23 \%$ and implies that chosen explanatory variables explain variations in the dependent variables to the tune of $90.23 \%$. Also, with a high Adjusted $\mathrm{R}^{2}(84.38 \%)$ implies that the model can take on more variables conveniently without the $\mathrm{R}^{2}$ falling beyond $84.38 \%$, which is very commendable. The Durbin-Watson of 1.857792 is considered good as it shows absence of autocorrelation on the chosen data.

Hence, from Table 8, the Nigerian stock market capitalization (SMC), has a t-statistic value of 2.938689 and a $P$-value of 0.0102 , was found to have a positive and statistically significant relationship and impact on economic development (HDI) and this impact is statistically significant at $5 \%$ level since its $p$-value is well above 0.05 . Therefore, we reject the null hypothesis, thus accepting the alternative hypothesis. This shows that the past level of SMC in Nigeria positively and significantly impacts economic development (HDI).

In Table 9, the $\mathrm{R}^{2}$ and Adjusted $\mathrm{R}^{2}$ both showed $98.66 \%$ and $98.49 \%$ respectively. This shows that the chosen regression model best fits the data. Hence, the goodness of fit regression model is $98.66 \%$ and implies that chosen explanatory

Table 8. ARDL Regression result for hypothesis one (Nigeria).

Dependent Variable: HDI

Method: ARDL

\begin{tabular}{ccccc}
\hline Dynamic regressors (1 lag, fixed): LOG(SMC) TR LOG (VST) ECM (-1) & & \\
\hline Variable & Coefficient & Std. Error & t-statistic & Prob. $^{*}$ \\
HDI(-1) & 0.540149 & 0.230239 & 2.346034 & 0.0331 \\
HDI(-2) & 0.387611 & 0.221138 & 1.752799 & 0.1000 \\
LOG(SMC) & 3.709381 & 1.262257 & $\mathbf{2 . 9 3 8 6 8 9}$ & $\mathbf{0 . 0 1 0 2}$ \\
LOG(SMC(-1)) & -2.431677 & 1.250988 & -1.943806 & 0.0709 \\
TR & 0.181285 & 0.098171 & 1.846626 & 0.0846 \\
TR(-1) & -0.117086 & 0.091607 & -1.278139 & 0.2206 \\
LOG(VST) & -3.726222 & 1.049285 & -3.551202 & 0.0029 \\
LOG(VST(-1)) & 2.475818 & 1.092608 & 2.265972 & 0.0387 \\
ECM(-1) & -0.609124 & 0.329173 & -1.850469 & 0.0840 \\
ECM(-2) & 0.100279 & 0.370942 & 0.270337 & 0.7906 \\
R-squared & 0.902389 & Mean dependent var & 47.40000 \\
Adjusted R-squared & 0.843822 & S. D. dependent var & 4.339739 \\
Durbin-Watson stat & 1.857792 & & & \\
\hline
\end{tabular}

Source: Computation by researcher using E-view 10.0. 
Table 9. ARDL Regression result for hypothesis one (Kenya).

\begin{tabular}{|c|c|c|c|c|}
\hline Dependent Variable: HDI & & & & \\
\hline Method: ARDL & & & & \\
\hline Dynamic regressors (1 lag, & natic): (SMC) & VST) & & \\
\hline Variable & Coefficient & Std. Error & t-statistic & Prob.* ${ }^{*}$ \\
\hline $\mathrm{HDI}(-1)$ & 1.005266 & 0.003986 & 252.1829 & 0.0000 \\
\hline SMC & $-1.63 \mathrm{E}-11$ & $2.77 \mathrm{E}-11$ & -0.587042 & 0.5627 \\
\hline TR & 0.002375 & 0.055923 & 0.042468 & 0.9665 \\
\hline VST & $7.82 \mathrm{E}-10$ & $3.16 \mathrm{E}-10$ & 2.474808 & 0.0208 \\
\hline R-squared & 0.986604 & Mean d & lent var & 50.50000 \\
\hline Adjusted R-squared & 0.984930 & S.D. de & ent var & 5.189020 \\
\hline Durbin-Watson stat & 1.570336 & & & \\
\hline
\end{tabular}

Source: Computation by researcher using E-view 10.0.

variables explain variations in the dependent variables to the tune of $98.66 \%$. Also, with a high Adjusted $\mathrm{R}^{2}(98.49 \%)$ implies that the model can take on more variables conveniently without the $\mathrm{R}^{2}$ falling beyond $98.49 \%$, which is very commendable. The Durbin-Watson statistics of 1.570336 is considered good as it shows absence of autocorrelation on the chosen data.

Hence, from Table 9, the Kenya SMC, has a t-statistic value of -0.587042 and a $P$-value of 0.5627 , was found to have a negative and insignificant relationship and does not impact on economic development and this impact is statistically insignificant at $5 \%$ level since its $P$-value is well above 0.05 . Therefore, we accept the null hypothesis. This shows that the past level of stock market capitalization (SMC) in Kenya negatively and insignificantly impact economic development (HDI).

In Table 10, the $\mathrm{R}^{2}$ and Adjusted $\mathrm{R}^{2}$ both showed $56.01 \%$ and $47.63 \%$ respectively. This shows that the chosen regression model moderately fits the data. Hence, the goodness of fit regression model is $56.01 \%$ and implies that the chosen explanatory variables explain variations in the dependent variables to the tune of $56.01 \%$. Also, with a moderate Adjusted $\mathrm{R}^{2}$ (47.63\%) implies that the model can take on more variables without the $\mathrm{R}^{2}$ falling beyond $47.63 \%$. At the intercept (constant) of the regression model the dependent variable $\mathrm{Y}$ has a value of 65.79731, when SMC, TR and VST (South Africa) are equal to zero (0). However, if SMC, TR and VST are increased by $1 \%$ the dependent variable $\mathrm{Y}$ will decrease by $-6.3512,-0.164812$ while increase by 4.2111 for SMC, TR and VST respectively. F-statistic of 6.685552 is considered very good being positive and significant enough and it shows that there is overall significant positive relationship between the dependent and explanatory variables. The overall probability (F-statistic) of 0.001237 is rightly signed and very significant and displays a Durbin-Watson of approximately 0.584 , which shows presence of autocorrelation on the chosen data. This therefore facilitated the needs for confirmatory test via heteroscedasticity test and Breusch-Godfrey test. 
Table 10. OLS Regression result for hypothesis one (South Africa).

\begin{tabular}{|c|c|c|c|c|}
\hline \multicolumn{5}{|c|}{ Dependent Variable: HDI } \\
\hline Variable & Coefficient & Std. Error & t-statistic & Prob. \\
\hline SMC & $-6.35 \mathrm{E}-12$ & $5.27 \mathrm{E}-12$ & -1.205948 & 0.2412 \\
\hline TR & -0.164812 & 0.079527 & -2.072392 & 0.0507 \\
\hline VST & $4.21 \mathrm{E}-11$ & $1.68 \mathrm{E}-11$ & 2.501133 & 0.0207 \\
\hline $\operatorname{ECM}(-1)$ & -0.485966 & 0.710862 & -0.683629 & 0.5017 \\
\hline $\mathrm{C}$ & 65.79731 & 2.055593 & 32.00892 & 0.0000 \\
\hline R-squared & 0.560138 & \multicolumn{2}{|c|}{ Mean dependent var } & 64.73077 \\
\hline Adjusted R-squared & 0.476354 & \multicolumn{2}{|c|}{ S. D. dependent var } & 3.000769 \\
\hline F-statistic & 6.685552 & \multicolumn{2}{|c|}{ Durbin-Watson stat } & 0.583650 \\
\hline Prob (F-statistic) & 0.001237 & & & \\
\hline
\end{tabular}

Source: Computation by researcher using E-view 10.0.

The low standard error of 5.2712 further confirms the strength and the predictive power of the beta coefficient of stock market capitalization (SMC). However, the t-statistic of -1.205948 with $p$-value of 0.2412 showed that the stock market capitalization (SMC) of South Africa has no relationship with economic development (HDI) with negatively insignificant signs within the period under review. Thus, the null hypothesis which states that stock market capitalization has no significant relationship with economic development in South Africa is accepted.

From Table 11, the $p$-value is less than the chosen level of significance of $5 \%$, confirming the presence of autocorrelation in the model. This is further enhanced with a Durbin-Watson statistic of 1.533092. Hence, we do not suspect any violation of the assumptions of classical linear regression.

The null hypothesis states that there is No heteroskedasticity if $P$-value is not significant and is greater than the chosen level of significance of $5 \%$. Hence, in this case, we accept the Null hypothesis that there is no evidence of heteroskedasticity since $P$-value is greater than 5\% significance level in Table 12 .

\section{Hypothesis One Decision}

Based on the findings and conclusion for Nigeria, Kenya and South Africa, the study therefore rejects the null hypothesis for Nigeria stating clearly that SMC has significant relationship with HDI while the study accepts the Null hypothesis that states that Stock Market Capitalization (SMC) have no significant relationship with economic development of Kenya and South Africa within the period under review (Table 13).

$\mathrm{H}_{\mathrm{o} 2}$ : Value of Stocks Traded had no significant relationship with Human Development Index (HDI) of selected Sub-Saharan African emerging economies.

$\mathrm{H}_{\mathrm{A} 2}$ : Value of Stocks Traded had significant relationship with Human Development Index (HDI) of selected Sub-Saharan African emerging economies.

From Table 14, the Nigeria VTS, has a t-statistic value of -3.551202 and a 
Table 11. BG serial correlation LM test.

\begin{tabular}{cccc}
\hline \multicolumn{4}{c}{ Breusch-Godfrey Serial Correlation LM Test: } \\
\hline F-statistic & 11.09430 & Prob. F (2, 19) & 0.0006 \\
Obs ${ }^{*}$ R-squared & 14.00639 & Prob. Chi-Square (2) & 0.0009 \\
\hline Source: Computation by researcher using E-view 10.0. & & \\
Table 12. Heteroskedasticity test. & & \\
\hline Heteroskedasticity Test: ARCH & Prob. F (1, 23) & 0.1476 \\
\hline F-statistic & 2.245801 & Prob. Chi-Square (1) & 0.1359 \\
\hline
\end{tabular}

Source: Computation by researcher using E-view 10.0.

Table 13. Summary of comparative result for hypothesis one.

\begin{tabular}{ccccccc}
\hline Variable & $\begin{array}{c}\text { t-statistic } \\
(\text { Prob) Nig. }\end{array}$ & Decision & $\begin{array}{c}\text { t-statistic } \\
(\text { Prob) Ken. }\end{array}$ & Decision & $\begin{array}{c}\text { t-statistic } \\
\text { (Prob) SA }\end{array}$ & Decision \\
\hline \multirow{2}{*}{ SMC } & $\begin{array}{c}2.938689 \\
(0.0102)\end{array}$ & Reject $\mathrm{Ho}_{1}$ & $\begin{array}{c}-0.587042 \\
(0.5627)\end{array}$ & Accept $\mathrm{Ho}_{1}$ & $\begin{array}{c}-1.205948 \\
(0.2412)\end{array}$ & Accept Ho $_{1}$ \\
& & & & \\
\hline
\end{tabular}

Source: Computation by researcher using E-view10.0.

Table 14. ARDL regression result for hypothesis two (Nigeria).

\begin{tabular}{|c|c|c|c|c|}
\hline \multicolumn{5}{|l|}{ Dependent Variable: HDI } \\
\hline \multicolumn{5}{|l|}{ Method: ARDL } \\
\hline \multicolumn{5}{|c|}{ Dynamic regressors (1 lag, fixed): LOG (SMC) TR LOG (VST) ECM (-1) } \\
\hline Variable & Coefficient & Std. Error & t-statistic & Prob. $^{*}$ \\
\hline $\operatorname{HDI}(-1)$ & 0.540149 & 0.230239 & 2.346034 & 0.0331 \\
\hline $\operatorname{HDI}(-2)$ & 0.387611 & 0.221138 & 1.752799 & 0.1000 \\
\hline LOG(SMC) & 3.709381 & 1.262257 & 2.938689 & 0.0102 \\
\hline $\operatorname{LOG}(\operatorname{SMC}(-1))$ & -2.431677 & 1.250988 & -1.943806 & 0.0709 \\
\hline TR & 0.181285 & 0.098171 & 1.846626 & 0.0846 \\
\hline $\mathrm{TR}(-1)$ & -0.117086 & 0.091607 & -1.278139 & 0.2206 \\
\hline LOG(VST) & -3.726222 & 1.049285 & -3.551202 & 0.0029 \\
\hline LOG(VST(-1)) & 2.475818 & 1.092608 & 2.265972 & 0.0387 \\
\hline $\operatorname{ECM}(-1)$ & -0.609124 & 0.329173 & -1.850469 & 0.0840 \\
\hline $\operatorname{ECM}(-2)$ & 0.100279 & 0.370942 & 0.270337 & 0.7906 \\
\hline
\end{tabular}

Source: Computation by researcher using E-view 10.0.

$P$-value of 0.0029 , was found to have a negative and statistically significant relationship with economic development at $5 \%$ level since its $P$-value is well below 0.05 . Therefore, we reject the null hypothesis to accept the alternative. The implication of this result is that VTS has a depressive effect on economic development in Nigeria and that a $1 \%$ increase in future VTS will result to a $-3.726222 \%$ 
falls in economic development (HDI) in Nigeria.

From Table 15, the Kenyan VTS, has a t-statistic value of 2.474808 and a $P$-value of 0.0208 , was found to have a positive and statistically significant relationship with economic development at $5 \%$ level since its $P$-value is well below 0.05. Therefore, we reject the null hypothesis to accept the alternative of significant relationship between Value of Stocks Traded had significant relationship with Human Development Index (HDI). The implication of this result is that VTS has an increasing effect on economic development in Kenya and that a $1 \%$ increase in future VTS will result to an increase to the tune of $7.8210 \%$ in economic development (HDI) in Kenya.

From Table 16, the South African VTS, has a t-statistic value of 2.501133 and a $P$-value of 0.0207 , was found to have a positive and statistically significant relationship with economic development at $5 \%$ level since its $P$-value is well below 0.05. Therefore, we reject the null hypothesis to accept the alternative of significant relationship between Value of Stocks Traded had significant relationship with Human Development Index (HDI) in South Africa. The implication of this result is that VTS has an increasing effect on economic development in South Africa and that a $1 \%$ increase in future VTS will result to an increase to the tune of $4.2111 \%$ in economic development (HDI) in South Africa.

\section{Hypothesis Two Decision}

Table 15. ARDL regression result for hypothesis two (Kenya).

\begin{tabular}{|c|c|c|c|c|}
\hline \multicolumn{5}{|c|}{ Dependent Variable: HDI } \\
\hline \multicolumn{5}{|l|}{ Method: ARDL } \\
\hline \multicolumn{5}{|c|}{ Dynamic regressors (1 lag, automatic): (SMC) TR (VST) } \\
\hline Variable & Coefficient & Std. Error & t-statistic & Prob. ${ }^{*}$ \\
\hline $\mathrm{HDI}(-1)$ & 1.005266 & 0.003986 & 252.1829 & 0.0000 \\
\hline SMC & $-1.63 \mathrm{E}-11$ & $2.77 \mathrm{E}-11$ & -0.587042 & 0.5627 \\
\hline TR & 0.002375 & 0.055923 & 0.042468 & 0.9665 \\
\hline VST & $7.82 \mathrm{E}-10$ & $3.16 \mathrm{E}-10$ & 2.474808 & 0.0208 \\
\hline
\end{tabular}

Source: Computation by researcher using E-view 10.0.

Table 16. OLS regression result for hypothesis two (South Africa).

\begin{tabular}{|c|c|c|c|c|}
\hline \multicolumn{3}{|c|}{ Dependent Variable: HDI } & \multirow[b]{2}{*}{ t-statistic } & \multirow[b]{2}{*}{ Prob. } \\
\hline Variable & Coefficient & Std. Error & & \\
\hline SMC & $-6.35 \mathrm{E}-12$ & $5.27 \mathrm{E}-12$ & -1.205948 & 0.2412 \\
\hline TR & -0.164812 & 0.079527 & -2.072392 & 0.0507 \\
\hline VST & $4.21 \mathrm{E}-11$ & $1.68 \mathrm{E}-11$ & 2.501133 & 0.0207 \\
\hline $\operatorname{ECM}(-1)$ & -0.485966 & 0.710862 & -0.683629 & 0.5017 \\
\hline $\mathrm{C}$ & 65.79731 & 2.055593 & 32.00892 & 0.0000 \\
\hline
\end{tabular}

Source: Computation by researcher using E-view 10.0. 
Based on the findings and conclusion for Nigeria, Kenya and South Africa, the study therefore rejects the null hypothesis for Nigeria, Kenya and South Africa stating clearly that VTS have significant relationship with HDI within the period under review. However, the Nigerian relationship between VTS and HDI was negatively significant while the other countries in Kenya and South Africa are positively significant (Table 17).

$\mathrm{H}_{03}$ : Stock Market Turnover had no significant relationship with Human Development Index (HDI) of selected Sub-Saharan African emerging economies.

$\mathrm{H}_{\mathrm{o}}$ : Stock Market Turnover had significant relationship with Human Development Index (HDI) of selected Sub-Saharan African emerging economies.

From Table 18, the Nigeria TR, has a t-statistic value of 1.846626 and a $P$-value of 0.0846 , was found to have a positive and statistically insignificant relationship with economic development at $5 \%$ level since its $P$-value is well above 0.05. Therefore, we accept the null hypothesis that Stock Market Turnover had no significant relationship with Human Development Index (HDI) in Nigeria to reject the alternative. The implication of this result is that a $1 \%$ increase in TR will result to a $0.181285 \%$ rise in economic development, showing an increasing insignificant effect of TR on economic development in Nigeria.

Table 17. Summary of comparative result for hypothesis two.

\begin{tabular}{ccccccc}
\hline Variable & $\begin{array}{c}\text { T-statistic } \\
\text { (Prob) Nig. }\end{array}$ & Decision & $\begin{array}{c}\text { T-statistic } \\
\text { (Prob) Ken. }\end{array}$ & Decision & $\begin{array}{c}\text { T-statistic } \\
\text { (Prob) SA }\end{array}$ & Decision \\
\hline \multirow{2}{*}{ VTS } & -3.551202 & Reject $\mathrm{Ho}_{1}$ & $\begin{array}{c}2.474808 \\
(0.0208)\end{array}$ & Reject $\mathrm{Ho}_{1}$ & $\begin{array}{r}2.501133 \\
(0.0207)\end{array}$ & Reject Ho $_{1}$ \\
\hline
\end{tabular}

Source: Computation by researcher using E-view 10.0.

Table 18. ARDL regression result for hypothesis three (Nigeria).

Dependent Variable: HDI

Method: ARDI

Dynamic regressors (1 lag, fixed): LOG (SMC) TR LOG (VST) ECM (-1)

\begin{tabular}{ccccc}
\hline Variable & Coefficient & Std. Error & t-statistic & Prob. $^{*}$ \\
\hline HDI(-1) & 0.540149 & 0.230239 & 2.346034 & 0.0331 \\
HDI(-2) & 0.387611 & 0.221138 & 1.752799 & 0.1000 \\
LOG(SMC) & 3.709381 & 1.262257 & 2.938689 & 0.0102 \\
LOG(SMC(-1)) & -2.431677 & 1.250988 & -1.943806 & 0.0709 \\
TR & $\mathbf{0 . 1 8 1 2 8 5}$ & $\mathbf{0 . 0 9 8 1 7 1}$ & $\mathbf{1 . 8 4 6 6 2 6}$ & $\mathbf{0 . 0 8 4 6}$ \\
TR(-1) & $-\mathbf{0 . 1 1 7 0 8 6}$ & $\mathbf{0 . 0 9 1 6 0 7}$ & -1.278139 & $\mathbf{0 . 2 2 0 6}$ \\
LOG(VST) & -3.726222 & 1.049285 & -3.551202 & 0.0029 \\
LOG(VST(-1)) & 2.475818 & 1.092608 & 2.265972 & 0.0387 \\
ECM(-1) & -0.609124 & 0.329173 & -1.850469 & 0.0840 \\
ECM(-2) & 0.100279 & 0.370942 & 0.270337 & 0.7906 \\
\hline
\end{tabular}

Source: Computation by researcher using E-view 10.0. 
From Table 19, the Kenya TR, has a t-statistic value of 0.042468 and a p-value of 0.9665 , was found to have a positive and statistically insignificant relationship with economic development at $5 \%$ level since its $p$-value is well above 0.05. Therefore, we accept the null hypothesis that Stock Market Turnover had no significant relationship with Human Development Index (HDI) in Kenya to reject the alternative. The implication of this result is that a $1 \%$ increase in TR will result to a $0.002375 \%$ rise in economic development, showing an increasing insignificant effect of TR on economic development in Kenya.

From Table 20, the South African TR, has a t-statistic value of -2.072392 and a $p$-value of 0.0507 , was found to have a negative and statistically significant relationship with economic development at $5 \%$ level since its $p$-value is well below 0.05. Therefore, we reject the null hypothesis to accept the alternative of significant relationship between Stock Market Turnover had significant relationship with Human Development Index (HDI) in South Africa. The implication of this result is that TR has an increasing effect on economic development in South Africa and that a $1 \%$ increase in future TR will result to a decrease in the tune of $-0.164812 \%$ in economic development (HDI) in South Africa.

\section{Hypothesis Three Decision}

Based on the findings and conclusion for Nigeria, Kenya and South Africa as summarized in Table 21, the study therefore rejects the null hypothesis for South

Table 19. ARDL regression result for hypothesis three (Kenya).

Dependent Variable: HDI

Method: ARDL

Dynamic regressors (1 lag, automatic): (SMC) TR (VST)

\begin{tabular}{ccccc}
\hline Variable & Coefficient & Std. Error & t-statistic & Prob. $^{*}$ \\
\hline HDI $(-1)$ & 1.005266 & 0.003986 & 252.1829 & 0.0000 \\
SMC & $-1.63 \mathrm{E}-11$ & $2.77 \mathrm{E}-11$ & -0.587042 & 0.5627 \\
TR & $\mathbf{0 . 0 0 2 3 7 5}$ & $\mathbf{0 . 0 5 5 9 2 3}$ & $\mathbf{0 . 0 4 2 4 6 8}$ & $\mathbf{0 . 9 6 6 5}$ \\
VST & $7.82 \mathrm{E}-10$ & $3.16 \mathrm{E}-10$ & 2.474808 & 0.0208 \\
\hline
\end{tabular}

Source: Computation by researcher using E-view 10.0.

Table 20. OLS regression result for hypothesis three (South Africa).

\begin{tabular}{|c|c|c|c|c|}
\hline \multicolumn{3}{|c|}{ Dependent Variable: HDI } & \multirow[b]{2}{*}{ t-statistic } & \multirow[b]{2}{*}{ Prob. } \\
\hline Variable & Coefficient & Std. Error & & \\
\hline SMC & $-6.35 \mathrm{E}-12$ & $5.27 \mathrm{E}-12$ & -1.205948 & 0.2412 \\
\hline TR & -0.164812 & 0.079527 & -2.072392 & 0.0507 \\
\hline VST & $4.21 \mathrm{E}-11$ & $1.68 \mathrm{E}-11$ & 2.501133 & 0.0207 \\
\hline $\operatorname{ECM}(-1)$ & -0.485966 & 0.710862 & -0.683629 & 0.5017 \\
\hline $\mathrm{C}$ & 65.79731 & 2.055593 & 32.00892 & 0.0000 \\
\hline
\end{tabular}

Source: Computation by researcher using E-view 10.0. 
Table 21. Summary of comparative result for hypothesis three.

\begin{tabular}{ccccccc}
\hline Variable & $\begin{array}{c}\text { T-statistic } \\
\text { (Prob) Nig. }\end{array}$ & Decision & $\begin{array}{c}\text { T-statistic } \\
\text { (Prob) Ken. }\end{array}$ & Decision & $\begin{array}{c}\text { T-statistic } \\
\text { (Prob) SA }\end{array}$ & Decision \\
\hline \multirow{2}{*}{ TR } & 1.846626 & ${\text { Accept } \mathrm{Ho}_{1}}$ & $\begin{array}{c}0.042468 \\
(0.9665)\end{array}$ & ${\text { Accept } \mathrm{Ho}_{1}}^{-2.072392}$ & ${\text { Reject } \mathrm{Ho}_{1}}^{(0.0507)}$ & \\
& $(0.0846)$ & & & & \\
\hline
\end{tabular}

Source: Computation by researcher using E-view 10.0.

Africa stating clearly that TR has significant relationship with HDI while the study accepts the Null hypothesis that states that Stock Market Turnover (TR) had no significant relationship with economic development represented by $\mathrm{Hu}$ man Development Index (HDI) in Nigeria and Kenya within the period under review.

\section{Discussion of Findings}

Objective One: To ascertain the relationship between stock market capitalization and economic development of selected Sub-Saharan African emerging economies.

The result of the regression analysis shows that stock market performance has positive and significant relationship with economic development of Nigeria, while Kenya and South Africa showed negative but insignificant relationship with economic development of Kenya and South Africa. The study showed that past levels of stock market capitalization was negatively related with Kenya and South Africa economic development in its negative t-statistics results of $(-0.587042$ and -1.205948$)$; however, the statistically insignificant relationship ( $p$-value of 0.5627 and 0.2412 ) with economic development in Kenya and South Africa at the $5 \%$ level of significance showed that stock market capitalization has an insignificant relationship with economic development in Kenya and South Africa. While in Nigeria, the statistically significant relationship between stock market capitalization and economic development in Nigeria at ( $p$-value 0.0102) of the $5 \%$ level of significance showed that stock market capitalization has a significant relationship with economic development in Nigeria. The coefficient of the past levels of stock market capitalization in $-1.63 \mathrm{E}-11$ and $-6.35 \mathrm{E}-12$ on Kenya and South Africa showed that stock market capitalization reduces economic development of Kenya and South Africa by $163.11 \%$ and $635.12 \%$ with every significant improvement in the stock market capitalization. While in Nigeria, the coefficient of the past levels of stock market capitalization in 3.709381 showed that stock market capitalization improves the Nigerian economic growth by $370.94 \%$ by every significant improvement in the stock market capitalization.

The result of this study for Nigeria is corroborated by the study of Okoro (2016) but contradicted by Osakwe and Ananwude (2017) while the findings of Osakwe and Ananwude (2017) and Ruwaydah and Ushad (2015); and Aduda, Masila, and Onsongo (2012) supported the position of findings in South Africa and Kenya respectively but contradicted by Cuthbert (2017) on South Africa. 
The results however showed that the position of findings is contradictory to previous findings in the literature for the three selected developing African economies.

A probable direct interpretation of this result is that the efforts of stock market capitalization were basically excessively high and idle in Kenya and South Africa; these funds raised are however unable to improve human development index (HDI) economic development while in Nigeria the stock market capitalization was regularly manifested to augment investment and developmental activities thus human development index (HDI).

Objective Two: To determine the relationship between total value of stocks traded and economic development of selected Sub-Saharan African emerging economies.

The result of the regression analysis shows that total value of stock has positive T-statistics of 2.474808 and 2.501133 with $P$-values of 0.0208 and 0.0207 which showed significant relationship with economic development of Kenya and South Africa respectively while the result also revealed that total value of stock has T-statistics of $(-3.551202)$ which prove negative and $p$-value of $(0.0029)$ that showed significant relationship with economic development of Nigeria. Thus, proving that past levels of total value of stock was negatively and significantly related with economic development in Nigeria while past levels of total value of stock showed positively and significant relationship Kenya and South Africa's economic development all at the $5 \%$ level of significance. The coefficient of the past levels of total value of stock in -3.726222 on Nigeria showed that total value of stock reduces economic development of Nigeria by $372.62 \%$ with every significant improvement in the total value of stock. While in Kenya and South Africa, the coefficient of the past levels of total value of stock in 7.82E-10 and $4.21 \mathrm{E}-11$ showed that total value of stock improves the Kenyan and South African economic development by $782.10 \%$ and $421.11 \%$ by every significant improvement in the total value of stock.

The result of this study for Kenya and South Africa is corroborated by the study of Ruwaydah and Ushad (2015); Adefeso, Egbetunde, and Alley (2013); Bilal, Chen, and Komal (2016) and Okoro (2016) but contradicted by Osakwe and Ananwude (2017) while the findings of Osakwe and Ananwude (2017) supported the position of findings in Nigeria but contradicted by Cuthbert (2017) on Nigeria. The results however showed that the position of findings is contradictory to previous findings in the literature for the three selected developing African economies.

A probable direct interpretation of this result is that the efforts of total value of stock were basically high and significantly improve economic development in Nigeria and the result is also same in Kenya and South Africa; these showed that total value of stock's funds raised is however able to improve human development index (HDI) economic development in the three countries in Nigeria, Kenya and South Africa. 
Objective Three: To examine the relationship between stock market turnover and economic development of selected Sub-Saharan African emerging economies.

The result of the regression analysis shows that stock market turnover has positive T-statistics of 1.846626 and 0.04468 with $P$-values of 0.0846 and 0.9665 which showed insignificant relationship with economic development of Nigeria and Kenya respectively while the result also revealed that stock market turnover has T-statistics of $(-2.072392)$ which prove negative and $p$-value of $(0.0507)$ that showed significant relationship with economic development of South Africa. Thus, proving that past levels of stock market turnover were negatively and significantly related with economic development in South Africa while past levels of stock market turnover showed positively and insignificant relationship Nigeria and Kenya's economic development all at the $5 \%$ level of significance. The coefficient of the past levels of stock market turnover in -0.164812 on South Africa showed that stock market turnover reduces economic development of South Africa by $16.48 \%$ with every significant improvement in the stock market turnover. While in Nigeria and Kenya, the coefficient of the past levels of stock market turnover in 0.181285 and 0.002375 showed that stock market turnover improves the Nigerian and Kenyan economic development by $18.12 \%$ and $0.24 \%$ by every insignificant improvement in the stock market turnover.

The result of this study for Nigeria and Kenya is corroborated with Aduda, Masila, and Onsongo (2012) in Kenya, Nwamuo (2018); Ihendinihu and Onwuchekwa (2012) in Nigeria, and the results are in line with Ake and Ognaligui (2010) in Cameroun but the results were also contradicted by previous findings in Yadirichukwu and Chigbu (2014) and Onwe (2015) in Nigeria and Nordin and Nordin (2016) in Malaysia. While in South Africa, the result is corroborated by the study of Ruwaydah and Ushad (2015) and contradicted by findings in Yartey and Adjasi (2007). The results however showed that the position of findings is contradictory to previous findings in the literature for the three selected developing African economies.

A probable direct interpretation of this result is that the efforts of stock market turnover were basically high and significantly improve economic development in South Africa and while the result showed improving but not significant improvement in the economic development of Nigeria and Kenya; these showed that stock market turnover is however unable to significantly improve human development index (HDI)/economic development in the two countries of Nigeria and Kenya while South Africa showed significant improvement of economic development of South Africa.

\section{Conclusion}

This research studied the nexus between capital market and economic development in selected emerging African economies following largely from the theoretical postulation of the Finance Led Growth Hypothesis theory. The theory 
holds that a well-functioning financial system will spur technological innovations through efficiency of resource allocation from unproductive sector to productive sector which will boost economic development, which constituted the focus of this work. Arguments in favour of the capital market and economic development and contradictions to the postulations were reviewed from empirical literature. Empirical analysis unbundled stock market performance index into Market capitalization, market turnover ratio, number of listed shares, value of stock traded and all share index in measuring the effect and this study however anchor its capital market performance on market capitalization, value of stock traded and stock market turnover ratio.

The need to domesticate the study of this relationship to our selected emerging African economies, contribute to current literature on subject, validate other scholars view point and use a more dynamic and robust analytical tool that captured the time series nature of the data involved motivated this study.

It was against the foregoing that the study chose a broad objective of examining capital market and economic development proxy by human development index (HDI) with evidence from selected emerging African economies focusing on three major economies namely-Nigeria, South Africa and Kenya.

The results emanating from our study proved that capital market has significant relationship with economic development of Nigeria and South Africa with only Kenya showing insignificant relationship between stock market performance and economic development. In conclusion, based on the outcome of our study, we affirm that capital market performance has a significant relationship with economic development in Nigeria and South Africa but showed insignificant effect of stock market performance on economic development in the selected emerging African economies in both short-run and long-run equilibrium periods.

\section{Recommendations}

Seeing that the results and conclusion of this work conforms with the Finance Led Growth Hypothesis Theory in the relationship study for Nigeria and South Africa, it is pertinent to further develop the capital markets performance of the emerging Sub-Saharan African economies in other to foster economic development. In line with this, government of Sub-Saharan African economies should improve basic infrastructures such as communication and information network and ensure the activities of stock market are human development oriented. This will enhance transactions between parties of the market (issuing house, stock brokers, investors etc.) and improve economic development; efforts should also be made to encourage a large market which will improve volume of stock traded which widens the prospect for economic development; and there should be formulation and implementation of incremental policies that will ensure improvement relative stock market turnover and its stability in the market-based stock market of the economy to foster human capital formation, increased investment, 
ensure stability in the financial system and human development at large.

Further study should endeavour to address a regional and panel data enshrined study on capital market and economic development of African economies on the aftermath of COVID 19 (Monthly data can be best for such study as the COVID 19 period is still fresh and on-going).

\section{Conflicts of Interest}

The authors declare no conflicts of interest regarding the publication of this paper.

\section{References}

Adefeso, H. A., Egbetunde, T., \& Alley, I. (2013). Stock Market Development and Growth in Nigeria: A Causal Analysis. Arabian Journal of Business and Management Review, 2, 78-94. https://doi.org/10.12816/0002295

Adeoye, A. A. (2015). Impact of the Nigerian Capital Market on the Economy. European Journal of Accounting Auditing and Finance Research, 3, 88-96.

http://www.eajournals.org/wp-content/uploads/Impact-of-the-Nigerian-Capital-Marke t-on-the-Economy.pdf

Aduda, J., Masila, J. M., \& Onsongo, E. N. (2012). The Determinants of Stock Market Development: The Case for the Nairobi Stock Exchange. International Journal of Humanities and Social Science, 2, 214-230.

Ake, B., \& Ognaligui, R. W. (2010). Financial Stock Market and Economic Growth in Developing Countries: The Case of Douala Stock Exchange in Cameroon. International Journal of Business and Management, 5, 82-88. https://doi.org/10.5539/ijbm.v5n5p82

Akinlo, A., \& Egbetunde, I. (2010). Financial Development and Economic Growth; the Experience of 10 Sub Saharan African Countries Revisited. The Review of Finance and Banking, 2, 17-28.

Anyanwu, J. C. (1993). Monetary Economics: Theory, Policy and Institution. Onitsha: Hybrid Publishers Limited.

Bilal, L., Chen, S., \& Komal, B. (2016). Impact of Stock Market Development on Economic Growth: Evidence from Lower Middle-Income Countries. Management and Administrative Sciences Review, 5, 86-97.

Brooks, C. (2014). Econometrics for Finance (2nd ed.). Cambridge: Cambridge University Press.

Cuthbert, T. T. (2017). Effect of Stock Market Development on Long-Run Economic Growth-Case of South Africa. Unpublished Master's Thesis, Cape Town, South Africa: The Graduate School of Business, University of Cape Town.

Goldsmith, R. W. (1969). Financial Structure and Development. New Haven, CT: Yale University Press.

Hailemariam, A., \& Guotai, C. (2014). Stock Market Development and Economic Growth: Empirical Evidence for Emerging Market Economies. International Journal of Economics, Finance and Management Sciences, 2, 171-181. https://doi.org/10.11648/j.ijefm.20140202.19

Ihendinihu, J. U., \& Onwuchekwa, J. C. (2012). Stock Market Performance and Economic Growth in Nigeria (1984-2011). Journal of Emerging Trends in Economics and Management Sciences, 3, 971-977.

Jhingan, M. L. (2005). Monetary Economics. Delhi: Vrinda Publications Ltd. 
Kareem, R., Sanni, S., Raheem, K., \& Bakare, H. (2013). The Impact of Capital Market on the Nigerian Economy. Journal of Economics and Sustainable Development, 4, 99-109.

Levine, R. (1996). Financial Development and Economic Growth: Views and Agenda. Journal of Economic Literature, 35, 688-726.

Levine, R., \& Zervos, S. (1998). Stock Markets, Banks, and Economic Growth. American Economic Review, 88, 537-558. https://doi.org/10.1596/1813-9450-1690

Mishkin, F. S. (2007). The Economics of Money, Banking and Financial Markets. Boston, MA: Greg Tobin.

Moime, D. (2016). Africa's Stock Exchanges Competitive in the Global Stock Markets. Legato Consultancy.

Ndako, U. B. (2009). Stock Markets, Banks and Economic Growth: Time Series Evidence from South Africa. Africametrics. http://www/africametrics.org/documents/conferences09/papers/Ndako-pdf

Nordin, S., \& Nordin, N. (2016). The Impact of Capital Market on Economic Growth: A Malaysian Outlook. International Journal of Economics and Financial Issues, 6, 259-265.

Nwamuo, C. (2018). Impact of Capital Market on the Economic Growth in Nigeria: An Empirical Analysis. IOSR Journal of Economics and Finance, 9, 48-59.

Nwaolisa, E. F., Kasie, E. G., \& Egbunike, C. F. (2013). The Impact of Capital Market on the Economic Growth of Nigerian Economy under Democratic Rule. Arabian Journal of Business and Management Review, 3, 53-62. https://doi.org/10.12816/0002371

Odhiambo, N. (2009). Stock Market Development and Economic Growth in South Africa: An ARDL-Bounds Testing Approach. WIBCONPRO.

https://doi.org/10.1016/j.enpol.2008.09.077

Ogege, S., \& Ezike, J. E. (2012). The Nigerian Capital Market and Economic Development: A Critical Appraisal. International Business Research, 5, 228-236. https://doi.org/10.5539/ibr.v5n8p228

Okoro, G. E. (2016). Stock Market Performance and the Augmentation of Frontier Economies: A Comparative Scrutiny of Nigeria and Mauritius. Studies and Scientific Researches Economics Edition, 23, 13-20. https://doi.org/10.29358/sceco.v0i23.337

Okoye, L. U., Modebe, N. J., Taiwo, J. N., \& Okorie, U. E. (2016). Impact of Capital Market Development on the Growth of the Nigerian Economy. Research Journal of Financial Sustainability Reporting, 1, 24-32.

Onwe, J. C. (2015). Nigerian Capital Market and Its Impact on Economy (1990-2013). Nigerian Journal of Economics and Development Studies, 1, 115-127.

Osakwe, C. I., \& Ananwude, C. A. (2017). Stock Market Development and Economic Growth: A Comparative Evidence from Two Emerging Economies in Africa-Nigeria and South Africa. Archives of Current Research International, 11, 1-15. https://doi.org/10.9734/ACRI/2017/38116

Osakwe, C. I., Ogbonna, K. S., \& Obi-Nwosu, V. O. (2020). Stock Market Capitalization and Economic Growth of Nigeria and South Africa. European Academic Research, 7, 5605-5623.

Rose, P. S., \& Marquis, M. H. (2009). Money and Capital Markets. New York: McGraw Hill.

Ruwaydah, A., \& Ushad, S. A. (2015). Effects of Stock Market Development on Economic Growth: The Case of SADC Countries. Proceedings of the Third Middle East Conference on Global Business, Economics, Finance and Banking.

Schumpeter, J. A. (1912). The Theory of Economic Development. Cambridge, MA: Har- 
vard University Press.

Soumaré, I., \& Tchana, F. T. (2015). Causality between FDI and Financial Market Development: Evidence from Emerging Markets. The World Bank Economic Review, 29, S205-S216. https://doi.org/10.1093/wber/lhv015

Statsza (2020). South Africa Statistical Economic Report.

Taiwo, J. N., Adedayo, A., \& Evawere, A. (2006). Capital Market and Economic Growth in Nigeria. Account and Financial Management Journal, 1, 497-525.

Tobias, O. O., \& Danson, K. (2011). Stock Market Performance and Economic Growth: Empirical Evidence from Kenya Using Causality Test Approach. Advances in Management and Applied Economics, 1, 153-196.

World Bank (2011). Market Capitalization of Listed Companies. World Development Indicators.

World Bank (2018). World Development Indicators.

World Bank (2019). World Development Indicators.

World Bank (2020). World Bank Economic Review. Quarterly Report.

Yadirichukwu, E., \& Chigbu, E. E. (2014). The Impact of Capital Market on Economic Growth: The Nigerian Perspective. International Journal of Development and Sustainability, 3, 838-864.

Yartey, C. A., \& Adjasi, C. K. (2007). Stock Market Development in Sub-Saharan Africa: Critical Issues and Challenges. IMF Working Papers, 2007, 33.

https://ideas.repec.org/s/imf/imfwpa.html

https://doi.org/10.5089/9781451867732.001 